\title{
Optimization of Methane Production Based on Mixture Content of Sewage Sludge, Food Waste, and Glycerol
}

\author{
Janaína dos Santos Ferreira ${ }^{1}$, Magali Christe Cammarota ${ }^{1}$ and I. Volschan Junior ${ }^{2}$ \\ 1. Biochemical Engineering Department, School of Chemistry, Federal University of Rio de Janeiro, Rio de Janeiro 21941-909, \\ Brazil \\ 2. Water Resources and Environmental Engineering Department, Polytechnic School, Federal University of Rio de Janeiro, Rio de
} Janeiro 21941-972, Brazil

Received: August 15, 2017 / Accepted: August 30, 2017 / Published: September 30, 2017

\begin{abstract}
This paper presents bench scale experiments related to anaerobic co-digestion of aerobic sewage sludge from a pilot WWTP (waste water treatment plants), raw glycerol from a biodiesel industry and food waste. Assays were conducted in $100 \mathrm{~mL}$ non-stirring penicillin vessels, at $30{ }^{\circ} \mathrm{C}$ and planned according to three optimization phases: (1) binary mixture of sewage sludge and FW (food waste); (2) binary mixture of sewage sludge and glycerol; and (3) ternary mixture of sewage sludge, FW, and glycerol. In the first and second phases, the highest SMP (specific methane production) was achieved by $10 \%(\mathrm{v} / \mathrm{v}) \mathrm{FW}$ and $0.5 \%$ (v/v) glycerol mixtures. The optimization of the ternary mixture during the third phase was reached by the combination of $10 \%$ (v/v) FW and $0.4 \%$ (v/v) glycerol. Despite the low SMP value, the addition of glycerol and FW contributed to doubling the SMP value of the sludge sample control.
\end{abstract}

Key words: Anaerobic digestion, co-digestion, sludge, organic fraction municipal solid waste, glycerol.

\section{Symbols and Abbreviations}

$\begin{array}{ll}\text { CESA } & \text { Environmental Sanitation Experimental } \\ \mathrm{CH}_{4} & \text { Center (CESA-UFRJ) } \\ \text { CHP } & \text { Combined heat and power unit } \\ \text { COD } & \text { Chemical oxygen demand } \\ \text { CSTR } & \text { Continuous stirred tank reactor } \\ \text { FW } & \text { Food waste } \\ \text { OFMSW } & \text { Organic fraction of municipal solid waste } \\ \text { RG } & \text { Raw glycerol } \\ \text { SCOD } & \text { Soluble chemical oxygen demand } \\ \text { SMP } & \text { Specific methane production } \\ \text { TA } & \text { Total alkalinity } \\ \text { TVA } & \text { Total volatile acids } \\ \text { VS } & \text { Volatile solids (= volatile total solids) } \\ \text { VSS } & \text { Volatile suspended solids } \\ \text { VSSD } & \text { Volatile suspended solids destruction } \\ \text { VTS } & \text { Volatile total solids } \\ \text { WWTP } & \text { Waste water treatment plant }\end{array}$

Corresponding author: Janaína dos Santos Ferreira, Doctoral Student, research field: anaerobic digestion.

\section{Introduction}

The gradual expansion of municipal sewerage and sewage treatment systems in Brazil increases the importance of knowledge about processes and technological routes that may improve sludge management efficiency at WWTP (waste water treatment plants). These processes include lower generation of sludge mass, higher generation of biomethane, and higher efficiency of methane use, and are as well as processes applied for material recovery and biosolid production.

Recovery of biomethane stands out as an attractive route to produce decentralized renewable energy, and its use in a WWTP will find different possible paths. The optimization of recovered energy use will depend on energy and sludge mass balances related to a specific route and on capital and expenditures. Recovered energy may be used for digester heating to impose thermophilic conditions and higher biogas 
production. As a fuel, methane may also be used for sludge volume reduction in thermal drying unit or for heat and power generation on the CHP unit. Of course, commercialized prices of the electric energy market as well as opportunities and costs related to final disposal, material recovery, and beneficial use of sludge mass are driving forces for process optimization and better management of WWTP.

Brazilian national solid waste policy establishes that before final disposal in a sanitary landfill, municipalities must practice residue recovery and residue treatment. To fulfill this requirement, a possible viable technology route may be to combine treatment of OFMSW (organic fraction of municipal solid waste) and sewage sludge in anaerobic digester units at the WWTP.

The co-digestion of sewage sludge with other high-carbon residues and different binary and ternary mixtures have been tested for anaerobic process optimization and higher methane generation. The combination of different organic substrates increases the diversity of carbon molecules structure, which improves anaerobic bacteria metabolism, destruction of volatile solids, and generation of biogas and methane [1-3]. In this context, OFMSW has been largely studied as a potential residue for co-digestion of sewage sludge $[4,5]$.

As a product with limited recovery options, Brazil faces the challenge of managing the significant generation $(594 \mathrm{kt} / \mathrm{yr})$ of residual glycerol produced by the biodiesel industry [6]. Due to its large amount of easily biodegradable carbon content, Athanasoulia et al. [7] and Jensen et al. [8] state that glycerol could be an appropriate residue for sewage sludge co-digestion.

Based on different reactor models, VTS (volatile total solids) and COD (chemical oxygen demand) volumetric loads, temperature conditions and hydraulic detention time, anaerobic co-digestion of binary and ternary mixtures containing glycerol and organic residues from different sources have been evaluated for the past 10 years. Although the results have shown that the addition of glycerol may favorably contribute for anaerobic process co-digestion, authors generally agree that different substrates must be combined under strict control due to initial organic load increase and mixture content of inhibitory as well as elements toxic to microorganism metabolism [9-11]. Carmona et al. [12] and Viana et al. [13] report that glycerol may present up to $46 \mathrm{~g}$ chloride/ $\mathrm{L}$, while a concentration between 5 and $9 \mathrm{~g}$ chloride/L is considered inhibitory for methanogenesis [14-17].

According to a review of literature, in a binary combination with sewage sludge, process optimization is limited to a concentration of glycerol up to $1 \%$ [19-25] or 2-3\% [7, 8]. In most of these studies, authors observed similar results with regard to raw glycerol limit concentration of $1 \%(\mathrm{v} / \mathrm{v})$, as it led to an organic overloading and a marked decrease in biogas production after a few days of operation. A rapid formation and accumulation of volatile acids and a consequent drop in $\mathrm{pH}$ values below those recommended for a good methanogenic activity have been suggested as the main causes. On the other hand, the same studies observed that concentrations equal to or less than $1 \%(\mathrm{v} / \mathrm{v})$ were able to impose a higher biogas production rate.

In combination with other organic wastes, the concentration of glycerol can be much larger. Physico-chemical structures of other substrates than sewage sludge probably offer better conditions to create resilient efforts on the final mixture and to support occasional effects due to organic load increase and mixture content of inhibitory and toxic elements, in special salinity.

Working with substrates other than sewage sludge with a ternary mixture of swine manure, corn silage, and $6 \%(\mathrm{v} / \mathrm{v})$ glycerol, Amon et al. [9] obtained an increase of $34 \%$ in specific methane production when compared to the binary mixture without glycerol. The research also indicated that a higher glycerol concent ration was able to decrease the biogas production.

Ma et al. [26] reported that methane production 
increased six times and achieved 57\% biogas composition, due to $85 \%$ of COD removal achieved during the co-digestion of potato industry effluent and glycerol. Working with swine manure and $20 \%(\mathrm{v} / \mathrm{v})$ of glycerol mixture, Astals et al. [27], indicated an increase of $125 \%$ in specific methane production when compared to just swine manure anaerobic digestion.

Under mesophilic conditions, Robra et al. [28], tested the co-digestion of bovine manure and 5\%, 10\%, and $15 \%(\mathrm{v} / \mathrm{v})$ glycerol, and they concluded that the results obtained under $10 \%$ and $15 \%$ were almost the same, with an increase of $14 \%$ in methane production. Heaven et al. [29] reported biodiesel industry efforts to produce biogas from the co-digestion of a ternary mixture of oleaginous, glycerol, and animal manure.

Regueiro et al. [1] compared co-digestion process of a ternary mixture of $84 \%$ swine manure, $5 \%$ fish processing waste, and $11 \%$ glycerol $(\mathrm{m} / \mathrm{m})$ with $100 \%$ swine manure. Biogas and methane production from the ternary mixture co-digestion reached values $50 \%$ and $10 \%$ higher, respectively, than those obtained from just the swine manure digestion.

According to Astals et al. [30], from the co-digestion of a binary mixture of swine manure and $4 \%(\mathrm{v} / \mathrm{v})$ glycerol, $62 \%$ removal of COD was obtained, which resulted in $64 \%$ increase of biogas production and 235 $\mathrm{mL} \mathrm{CH}_{4} / \mathrm{g} \mathrm{VTS}_{\text {applied }}$ of specific methane production. Martin et al. [31] reported a specific methane production of $385 \mathrm{~mL} \mathrm{CH} / \mathrm{g} \mathrm{VTS}$ applied derived from the co-digestion of orange peel and glycerol.

Based on two different studies, Serrano et al. [32], compared the specific methane production obtained during the co-digestion of a binary mixture of strawberry waste and fish processing waste, and a ternary mixture, in which one glycerol was added. The result indicated that $230 \mathrm{~mL} \mathrm{CH} / \mathrm{CH}_{4} \mathrm{VTS}_{\text {applied }}$ was achieved during the first case, while the second case was able to produce $308 \mathrm{~mL} \mathrm{CH}_{4} / \mathrm{g} \mathrm{VTS}_{\text {applied. }}$.

Maranón et al. [33] suggested the co-digestion of sewage sludge, glycerol, and OFMSW as an interesting strategy for higher methane generation in anaerobic digesters, but they also observed that process optimization depends on mixture content and nutrients load.

To find key elements around the proposal of Maranón et al. [33], and in order to contribute to national issues related to municipal solid waste and glycerol residue management, this paper present results are obtained from a bench scale experiment of which main objective was to optimize methane production during anaerobic co-digestion of sewage sludge, glycerol, and food waste.

\section{Material and Methods}

Considering the proposal to optimize ternary mixture co-digestion, the experimental design was planned according to three phases. The first was dedicated to the co-digestion optimization of a binary mixture of sewage sludge and FW (food waste); the second was based on sewage sludge and glycerol mixture; and according to those results, the third evaluated the co-digestion of the ternary mixture itself.

Excess activated sludge from a municipal WWTP located in Rio de Janeiro (WWTP Sludge) and disintegrated and homogenized food waste from a university restaurant was used during the first experimental phase. The FW was liquefied by the addition of distilled water in order to achieve similar water content as the sludge mass. This first phase was planned according to two different experiments, which varied the content of sludge and FW (v/v) in the mixture. The first focused on a higher FW content, based on (\% v/v) 100:0, 80:20, 60:40, 40:60, and 20:80 ratios, while the second focused on a lower content of FW and based on (\% v/v) 90:10; 85:15; 80:20, and 75:25 ratios.

Excess activated sludge from a municipal WWTP located in Rio de Janeiro (WWTP Sludge) and residual glycerol from a biodiesel industry were used during the second experimental phase. Bovine fat and soybean oil were the basic sources of the biodiesel production 
process. Residual glycerol was collected after particle separation and alcohol (methanol) recovery phases. According to literature review, $1 \%$ glycerol content was the reference value for the second phase experiments. Preliminary results indicated that $1 \%(\mathrm{v} / \mathrm{v})$ raw glycerol compromised the overall performance of co-digestion process and further experiments were based on $0.8,0.5$, and $0.3 \%(\mathrm{v} / \mathrm{v})$ of raw glycerol content.

Based on the results of the first two phases, and to better evaluate the interaction between all variables involved in the co-digestion of sewage sludge, FW and glycerol, a complete factorial experiment $3^{2}$ (with 3 central points, totaling 11 assays with 5 replicates each) was planned for the third phase, considering 2 variables (glycerol and FW concentration) and 3 levels (-1, 0 and $+1)$. From the first experimental phase, $0 \%(\mathrm{v} / \mathrm{v}), 10 \%$ $(\mathrm{v} / \mathrm{v})$, and $20 \%(\mathrm{v} / \mathrm{v})$ of FW were selected as $-1,0$, and +1 level, while $0 \%(\mathrm{v} / \mathrm{v}), 0.4 \%(\mathrm{v} / \mathrm{v})$, and $0.8 \%(\mathrm{v} / \mathrm{v})$ of glycerol were selected as $-1,0$, and +1 level for the second phase. Statistica 8 software (StatSoft) was applied for variance analysis with $95 \%$ of confidence level $(p<0.05)$ and VSSD (volatile suspended solids destruction) and SMP (specific methane production) were selected as response variables.

Bench scale experiments were planned in order to support and guide future pilot scale experiments at the Environmental Sanitation Experimental Center of the Federal University of Rio de Janeiro, and excess activated sludge from its pilot plant (CESA Sludge) was used in the third experimental phase. FW belonged to the same food waste source and was prepared according to the same conditions as the first experimental phase. The same glycerol used in the second phase was used during the third phase.

Assays were conducted in $100 \mathrm{~mL}$ non-stirring penicillin vessels, at $30{ }^{\circ} \mathrm{C}$. After the mixture was introduced, vessels were closed with rubber bumpers and aluminium seal and connected to a $60 \mathrm{~mL}$ plastic syringe. Biogas volume production was measured daily according to syringe plunger displacement (measured volumes are presented at $30{ }^{\circ} \mathrm{C}$ and $\left.1 \mathrm{~atm}\right)$. After stabilization, biogas samples were extracted and analyzed by gas chromatography to quantify methane content; vessels were also opened for sampling and analysis of digested content. Initial and final values of $\mathrm{pH}$ and VS concentration were measured during the 3 phases.

Before sewage sludge addition, glycerol was diluted by distilled water according to $1: 10$ ratio and $\mathrm{pH}$ was corrected to 7.0 and 7.5 values by the addition of sodium bicarbonate. During all the phases, at least 4 replicates of experiments were conducted and mean values are presented as final values.

Carbohydrates and proteins were determined according to Dubois et al. [34] and Lowry et al. [35]. TVA (total volatile acids) and TA (total alkalinity) were determined according to DiLallo and Albertson [36] and Ripley et al. [37]. Glycerol content was measured according to Bondiolli and Bella [38]. Oil and fat, soluble COD (SCOD), and VS concentrations were measured according to standard procedures [39].

Table 1 Characteristics of the sludge and FW used during the experimental phases.

\begin{tabular}{llllll}
\hline \multirow{2}{*}{ Parameter } & 1st phase & 2nd phase & 3rd phase & & \\
\cline { 2 - 6 } & WWTP sludge & FW & WWTP sludge & CESA sludge & FW \\
\hline pH & 6.9 & 5.2 & 6.8 & 6.9 & 5.5 \\
Humidity (\%) & 97.8 & 73.2 & 96.5 & 93.5 & 78.5 \\
Carbon (\%) & 34.7 & 51.6 & 34.7 & - & 53.5 \\
Nitrogen (\%) & 5.4 & 8.0 & 5.4 & - & 8.5 \\
Phosphorus (\%) & - & 0.03 & - & - & 0.05 \\
TS (mg/g) & 19.7 & 267.7 & 14.1 & 12.2 & 236.6 \\
VTS (mg/g) & 11.8 & 251.4 & 8.8 & 8.2 & 212.5 \\
\hline
\end{tabular}

\footnotetext{
${ }^{\mathrm{a}}$ wet content.
} 


\section{Results and Discussion}

\subsection{Substrate Composition}

Table 1 presents characteristics of the sludge and FW used during the experimental phases. In general, $\mathrm{pH}$ values presented by each substrate were an indication that binary and ternary mixtures should be corrected in order to achieve $\mathrm{pH}$ value closed to neutrality. FW presented higher content of dry solids than sludge, and the addition of distilled water was required for better disintegration and homogenization.

Carbon and nitrogen content of WWTP and CESA sludges were lower than in FW, which indicates that the addition of a higher carbon content source may improve the performance of the anaerobic digestion process.

During the second and third experimental phases, FW presented $69.8 \mathrm{mg} / \mathrm{g}$ and $50.1 \mathrm{mg} / \mathrm{g}$ of oil and fats, respectively, values that represented $59 \%$ and $48 \%$ of the chemical composition of the food waste. Therefore, lipid molecules are more complex to biodegrade than carbohydrates and proteins, and this should influence biogas and methane production.

Substrate analysis showed that total solid content of FW was mostly due to organic particles, while VTS:TS ratio in sewage sludge varied from just 0.5 in WWTP sludge to 0.67 in CESA Sludge. VTS concentration in FW confirmed its high carbon content.

Even CESA sludge presented carbon and nitrogen ratio higher than that presented by WWTP sludge and FW. The values were much lower than those generally suggested for anaerobic digestion and comprised from 20 to 30 [40]. This fact may also influence the performance of anaerobic co-digestion process as well as production of biogas and methane.

From a biodiesel production process that was based on bovine fat and soybean oil sources and after particle separation and alcohol recovery phases, residual glycerol used during the second and third phases presented the following characteristics: $74 \%(\mathrm{~m} / \mathrm{m})$ glycerol; 37,100 $\mathrm{mg} \mathrm{Cl}^{-} / \mathrm{L} ; 19 \mathrm{mg}$ methanol/L; 1,119 mg COD/L, and $411 \mathrm{~g}$ total Carbon /L. Salinity value was closed to $46 \mathrm{~g} \mathrm{Cl}^{-} / \mathrm{L}$, which corresponded to that indicated by Carmona et al. [12] and Viana et al. [13]. The option to use raw glycerol containing high salinity content was justified by the fact that previous assays indicated that even $1 \%$ treated glycerol was able to compromise the overall performance of the co-digestion process.

\subsection{First Experimental Phase: Sludge and FW Co-digestion}

The first experimental phase was comprised of two different assays. One focused on a higher food waste content and was based on 100:0, 80:20, 60:40, 40:60, and 20:80 sludge to FW ratios. Fig. 1 shows $\mathrm{pH}$ drop and VS removal (\%) at the end of the first co-digestion assay.

The results indicated that addition of FW increased biogas volume, probably due to the presence of rapidly biodegradable organic content on the binary mixture. During the first 2 days of the assay, for every (\%) of FW content, a higher biogas volume production compared to sewage sludge sample control was observed. However, from the third day of experiment, for every FW content, excess accumulation of volatile acid, lower buffer capacity, and decreased $\mathrm{pH}$ up to 3.3 ( $80 \%$ of FW) strongly inhibited biogas production. Even after initial correction of $\mathrm{pH}$ value to 7.0 , the higher the content of food waste is, the lower the $\mathrm{pH}$ values of the digested mixture are after stabilization. While the sewage sludge sample control presented final $\mathrm{pH}$ values equal to 6.7 , the 60:40, 40:60, and 20:80 ratios presented final $\mathrm{pH}$ values equal or lower than 5.1. The $\mathrm{pH}$ drop influenced the stabilization of the process, resulting at the end of the experiment in VS destruction values lower than $30 \%$.

Kim and Kang [41], also verified inhibition of specific methane production after the third day of co-digestion process due to the increase of food waste leachate content $(\mathrm{F})$ in the ternary mixture $(1 \mathrm{~S}: 4 \mathrm{~F}: 1 \mathrm{~A})$ with raw sludge (S), and algal biomass (A). According 


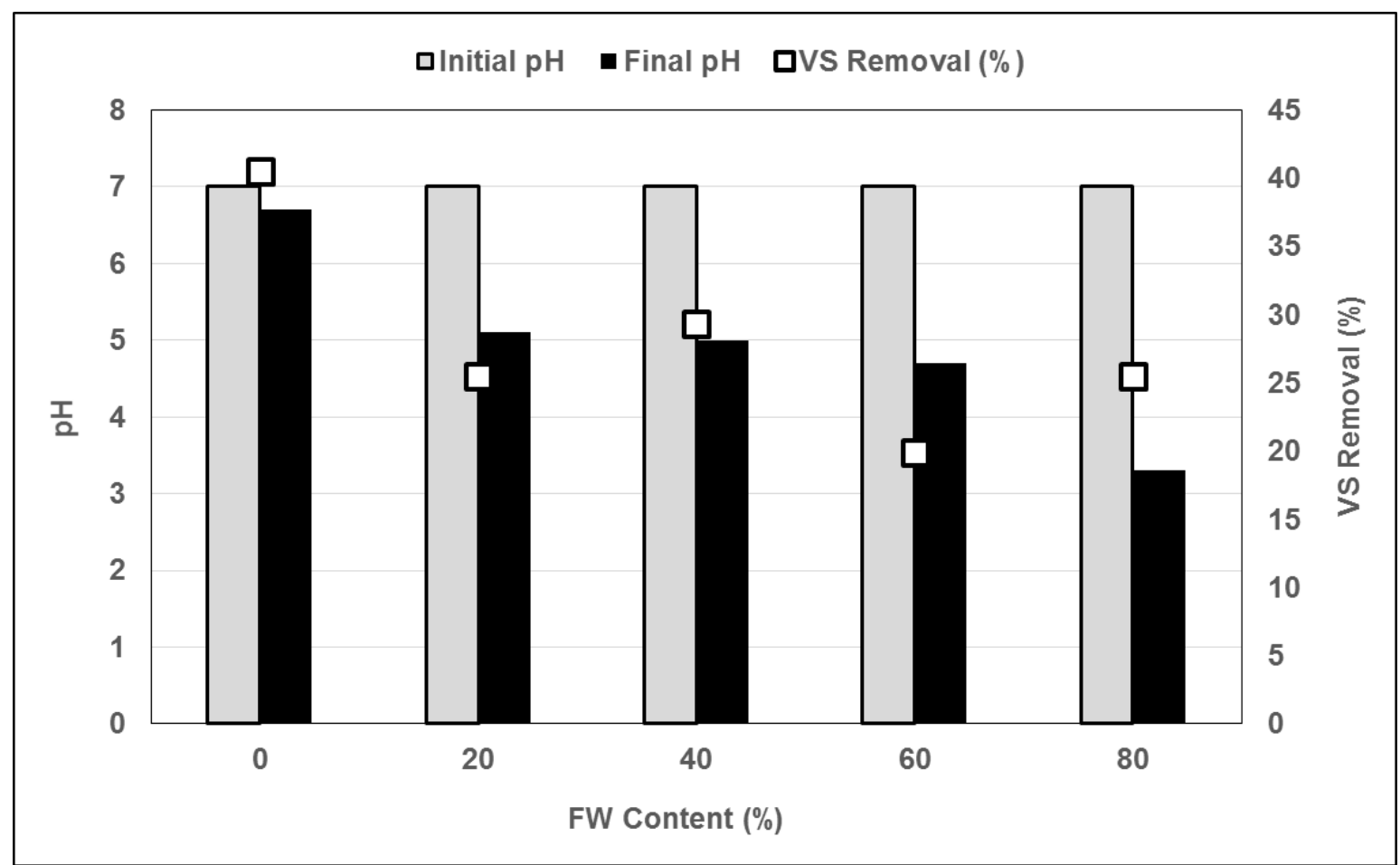

Fig. 1 Initial and final pH and VS removal values achieved by first co-digestion assay.

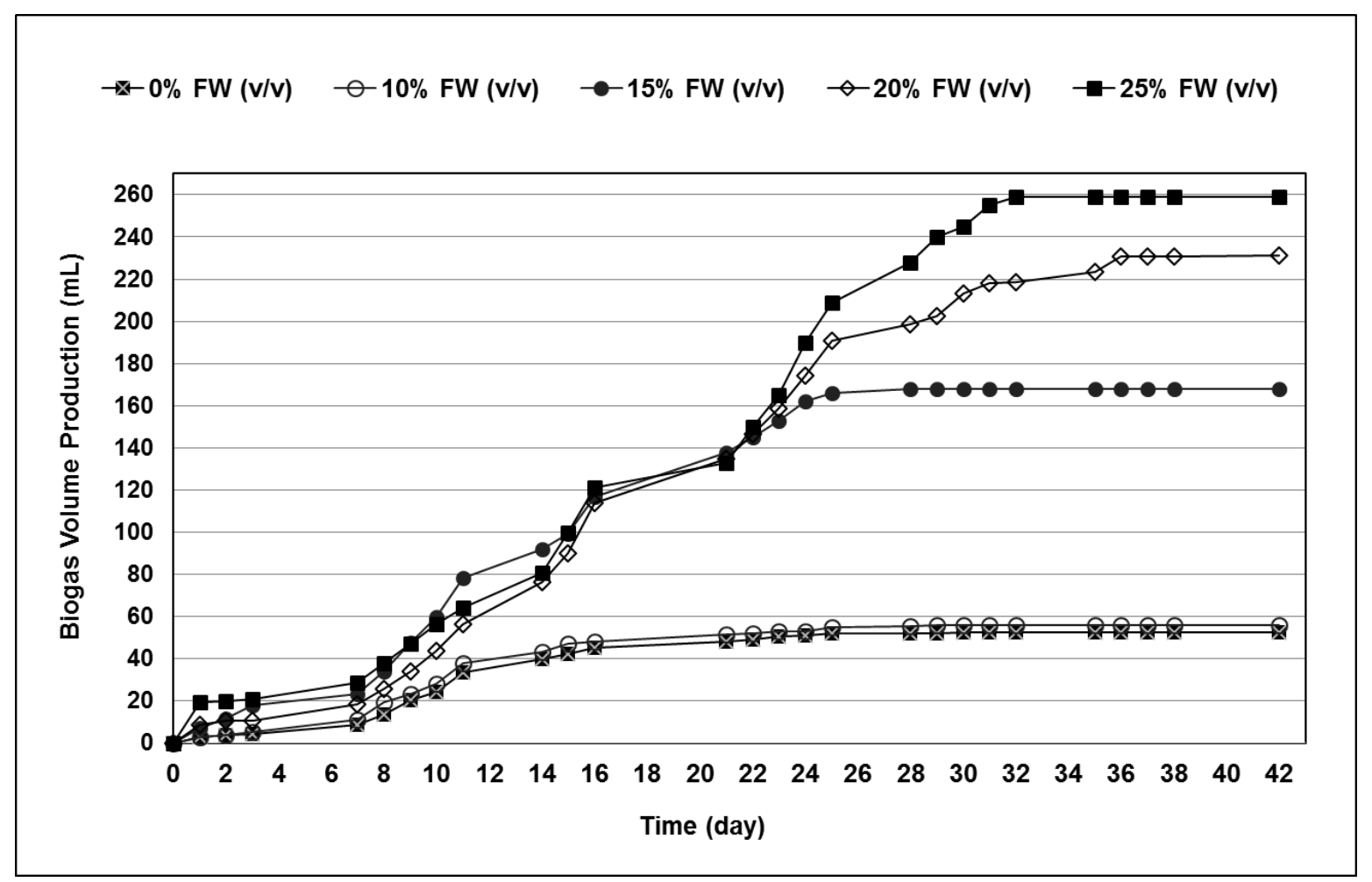

Fig. 2 Biogas volume production achieved by second co-digestion assay. 
to increased OFMSW content, Gou et al. [4] varied the volumetric organic load of the binary mixture with sewage sludge, from 1 to $8 \mathrm{~g}$ VTS/L.d., and in a continuous process co-digestion they observed a $\mathrm{pH}$ drop from 7.0 to 4.9 and $43 \%$ of VTS removal.

Therefore, the second assay limited the addition of FW up to $25 \%(\mathrm{v} / \mathrm{v})$. As shown in Fig. 2, for any mixture ratio, co-digestion process presented the expected pattern with regard to time for production of biogas, and stabilization was generally reached after 35 days. The correction of initial $\mathrm{pH}$ value to 7.5 contributed for co-digestion buffer capacity and final $\mathrm{pH}$ values were higher than 7.0 for any FW content.

As shown in Fig. 3, the addition of FW generally increased production of biogas. Binary composition according to $75: 25$ ratio achieved values up to $259 \mathrm{~mL}$, a volume almost 5 times higher than that produced by 100:0 control ratio $(53 \mathrm{~mL})$.

Sewage sludge sample control and $10 \% \mathrm{FW}$ content reached almost the same VTS removal (27\% and 25\%) and biogas volume production $(53 \mathrm{~mL}$ and $56 \mathrm{~mL})$. A higher methane content in biogas always responded to the presence of FW, even with lower content mixture $10 \%(\mathrm{v} / \mathrm{v})$ and according to values up to $84 \%$.

Considering these results, $20 \%$ and $25 \%$ (v/v) ratios corresponded to the optimal condition for methane generation, as they presented the highest biogas volume production ( $231 \mathrm{~mL}$ and $259 \mathrm{~mL}$ ) with high methane content $(74 \%$ and $71 \%)$. The same figure shows that the highest SMP based on $\mathrm{VTS}_{\text {applied }}$ load was related to $75: 25$ ratio $\left(116 \mathrm{~mL} \mathrm{CH}_{4} / \mathrm{g} \mathrm{VTS}_{\text {applied }}\right)$, a value 4.3 times higher than the sewage sludge sample control. Kim et al. [42] evaluated the co-digestion of sludge $(80 \%)$ and food waste $(20 \%)$ and obtained for $71 \%$ methane content, which is a SMP 1.4 times higher.

The increase in FW content in the binary mixture also corresponded to an increase of VTS $\mathrm{V}_{\text {applied }}$ load and consequently in the increase of the SMP. A better equilibrium between successive steps of anaerobic degradation process, especially a well balanced acidogenesis phase, may justify the better performance of the $75: 25$ ratio mixtures.

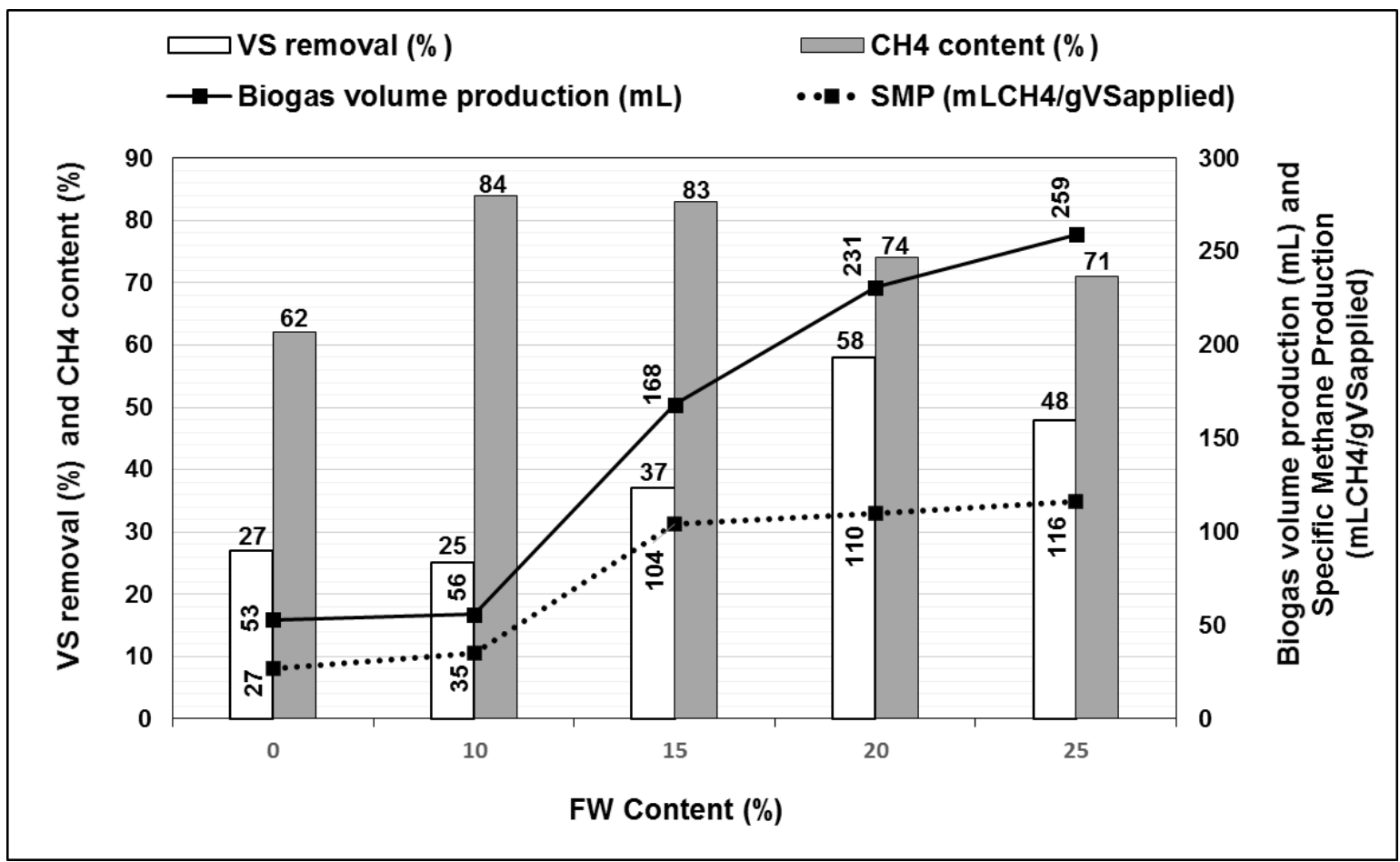

Fig. 3 Biogas volume production, VS removal, $\mathrm{CH}_{4}$ content, and specific methane production according to different mixture ratios of sludge and $\mathrm{FW}$. 


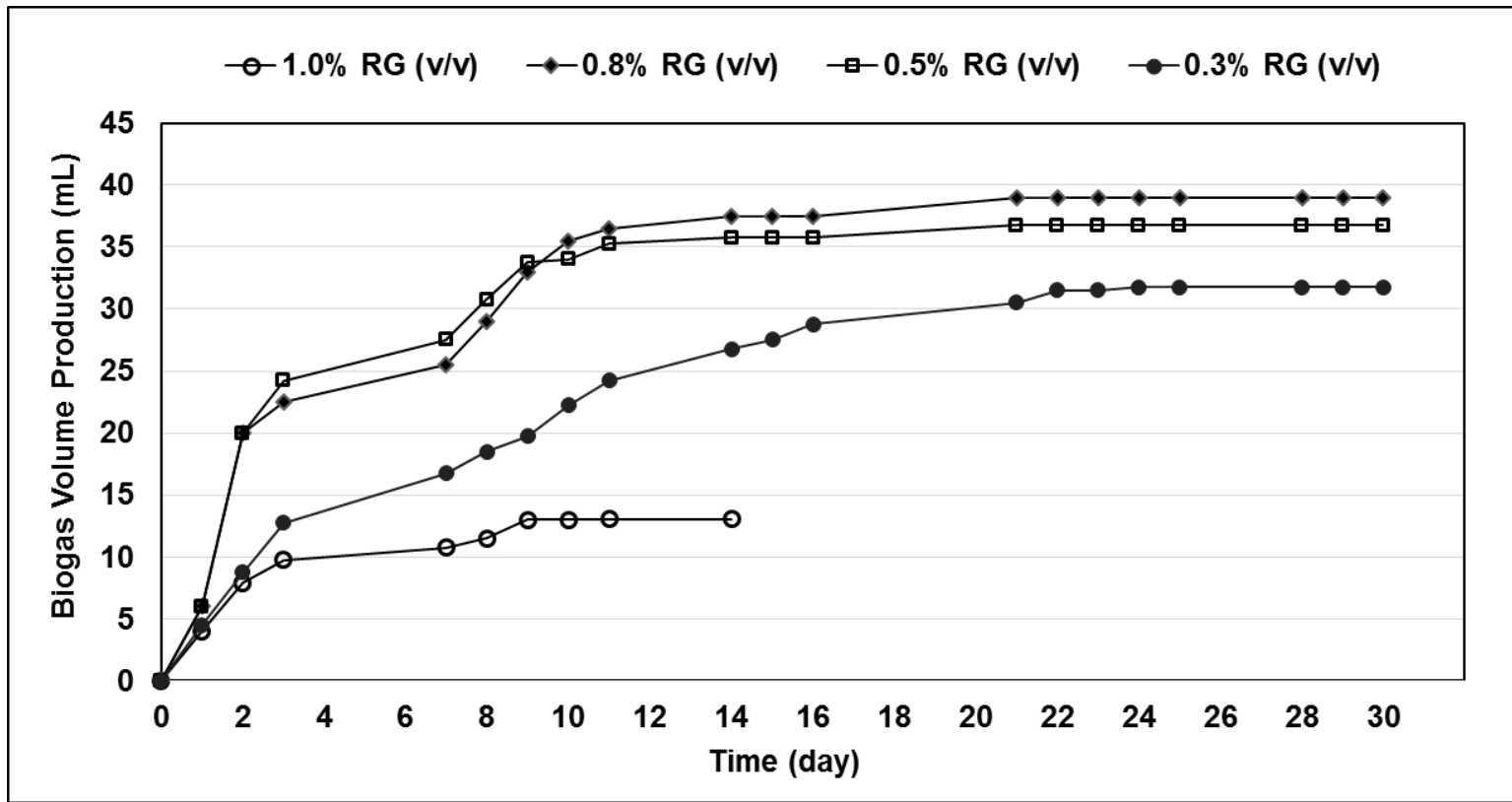

Fig. 4 Biogas volume production during sludge and glycerol co-digestion.

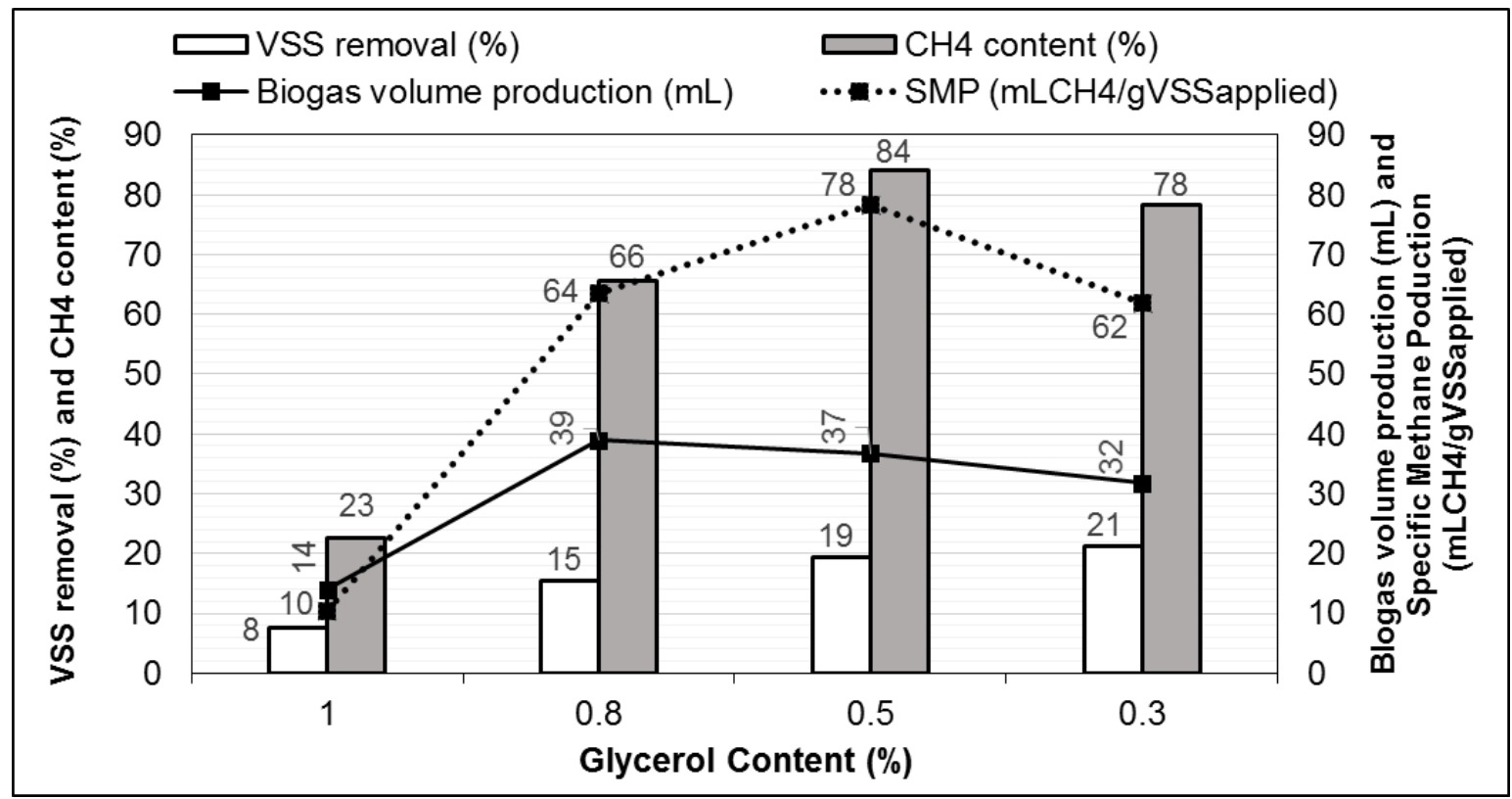

Fig. 5 Biogas volume production, VSS removal, $\mathrm{CH}_{4}$ content, and specific methane production according to different mixture ratios of sludge and glycerol.

\subsection{Second Experimental Phase: Sludge and Glycerol Co-digestion}

The second experimental phase consisted of just one assay. Based on a literature review and on preliminary test results, the experiment was planned in order to evaluate the effects of glycerol on co-digestion process with content values lower than $1.0 \%(\mathrm{v} / \mathrm{v})$. As shown in Fig. 4, 1.0\% (v/v) content had limited biogas production. Just based on biogas volume production criteria and in order to compose the ternary mixture, results indicate that biogas volume production increased according to the addition of glycerol and that it should be limited to $0.8 \mathrm{mg} / \mathrm{L}$.

On the other hand, Fig. 5 indicates that the presence of glycerol restricted VSS (volatile suspended solids) removal ratio up to only $21 \%$, which is a lower value 
than the conventional 50\% removal ratio usually reached by anaerobic digestion process. Athanasoulia et al. [7] also reported a decrease in VTS reduction from $36 \%$ to $24 \%$ by adding $3 \%$ (v/v) of glycerol to the sludge in a CSTR. VSS removal was increased according to glycerol content decrease, and it may be an indication that residual glycerol from biodiesel industry presents a chemical composition and a molecular structure that impair bacteria metabolism and anaerobic process efficiency. The lower VSS removal in the sewage sludge and glycerol mixtures may have occurred due to the higher availability of carbon from the glycerol, contributing to the maintenance of the still active biomass and reducing the stabilization of the VTS [19].

Even based on the highest VSS removal ratio, $0.3 \%$ glycerol mixture $(\mathrm{v} / \mathrm{v})$ was not able to produce the highest volume and methane content in biogas. The highest SMP (78 $\mathrm{mL} \mathrm{CH}_{4} / \mathrm{g} \mathrm{VSS}$ applied) was reached by $0.5 \%$ glycerol content $(\mathrm{v} / \mathrm{v})$, due to its highest methane biogas concentration (84\%).

Several authors related an SMP increase and the high biodegradability level of glycerol (above $85 \%$ ) in a binary mixture co-digestion with sewage sludge. From co-digestion process of sewage sludge and treated glycerol, Siles López et al. [20] reported a specific methane production of $0.306 \mathrm{~m}^{3} \mathrm{CH}_{4} / \mathrm{kg}$ of treated glycerol. Fountoulakis et al. [19] verified that the addition of $1 \%$ of raw glycerol ( $/ \mathrm{v}$ ) to sludge presented the best result in terms of biogas production $(2,353 \pm 94 \mathrm{~mL} / \mathrm{d})$ and that the addition of higher values caused process instability and biogas production decrease. Baba et al. [18] suggested that daily glycerol load must be gradually increased in order to optimize methane production rate and indicated that $90 \%$ of COD removal and a specific biogas production of 358 $\mathrm{mL} / \mathrm{g}$ of removed COD was obtained for a mixture content of $1 \%$ of glycerol (v/v) and sludge. Athanasoulia et al. [7] varied the addition of glycerol to sludge from 0 to $4 \%(\mathrm{v} / \mathrm{v})$ and concluded that under $3 \%$ condition, the best biogas production equal to $150 \mathrm{~L} / \mathrm{d}$ was accomplished, a value 5 times higher than the one without glycerol. Nghiem et al. [21], evaluated the co-digestion of 0.63 up to $3.00 \%$ (v/v) of raw glycerol and sludge mixture, and they reported that the lowest raw glycerol content presented the best result in terms of biogas production, achieving $1.3 \mathrm{~m}^{3} \mathrm{CH}_{4} / \mathrm{L}$ applied raw glycerol.

Razaviarani et al. [22, 23] added up to $1.8 \%(\mathrm{v} / \mathrm{v})$ of raw glycerol to sludge and deduced that co-digestion optimization was related to the specific production of $880 \mathrm{~mL} \mathrm{CH} / \mathrm{g} \mathrm{VTS}_{\text {applied, }}$ a value obtained by the addition of just $1.0 \%$ raw glycerol. Later, the same authors reported inhibitory effects to anaerobic co-digestion by the addition of $1.8 \%(\mathrm{v} / \mathrm{v})$ and that $1.1 \%$ (v/v) addition was able to increase VTS destruction and biogas production [25]. Values obtained by Jensen et al. [8], under $2 \%$ of glycerol were $75 \%$ VTS removal and $490 \mathrm{~mL} \mathrm{CH}_{4} / \mathrm{g} \mathrm{VTS}_{\text {applied. }}$ Silvestre et al. [25] reported that $1 \%$ raw glycerol addition to sludge $(\mathrm{v} / \mathrm{v})$ resulted on 58\% VTS removal and a specific methane production of $325 \mathrm{~mL} \mathrm{CH}_{4} / \mathrm{g} \mathrm{VTS}_{\text {applied. }}$.

With the addition of $2.7 \%(\mathrm{v} / \mathrm{v})$ of raw glycerol to sludge, which represented an organic load of $2.1 \mathrm{~g}$ VTS/L.d., Nartker et al. [3] observed that methane production was increased in $82 \%$, achieving a specific methane production equal to $920 \mathrm{~mL} \mathrm{CH}_{4} / \mathrm{g} \mathrm{VTS}_{\text {removed. }}$. Rivero et al. [24] evaluated a mixture content of $1 \%$ $(\mathrm{v} / \mathrm{v})$ of glycerol and sludge, obtaining $89 \%$ of VTS removal and a specific methane production of $148 \mathrm{~mL}$ $\mathrm{CH}_{4} / \mathrm{g} \mathrm{VTS}_{\text {removed. }}$

\subsection{Third Experimental Phase: Sludge, FW, and Glycerol Co-digestion}

Based on the results of the first two experimental phases, the third one focused on optimization of methane production during anaerobic co-digestion of sewage sludge, glycerol, and FW. At this phase, 11 trials were done to a complete factorial design $3^{2}$. Fig. 6 shows the VSS removal (\%) and SMP $\left(\mathrm{mL} \mathrm{CH}_{4} / \mathrm{g}\right.$ $\mathrm{VSS}_{\text {applied }}$ ) results obtained according to the ternary mixture composition $(\% \mathrm{v} / \mathrm{v})$. 


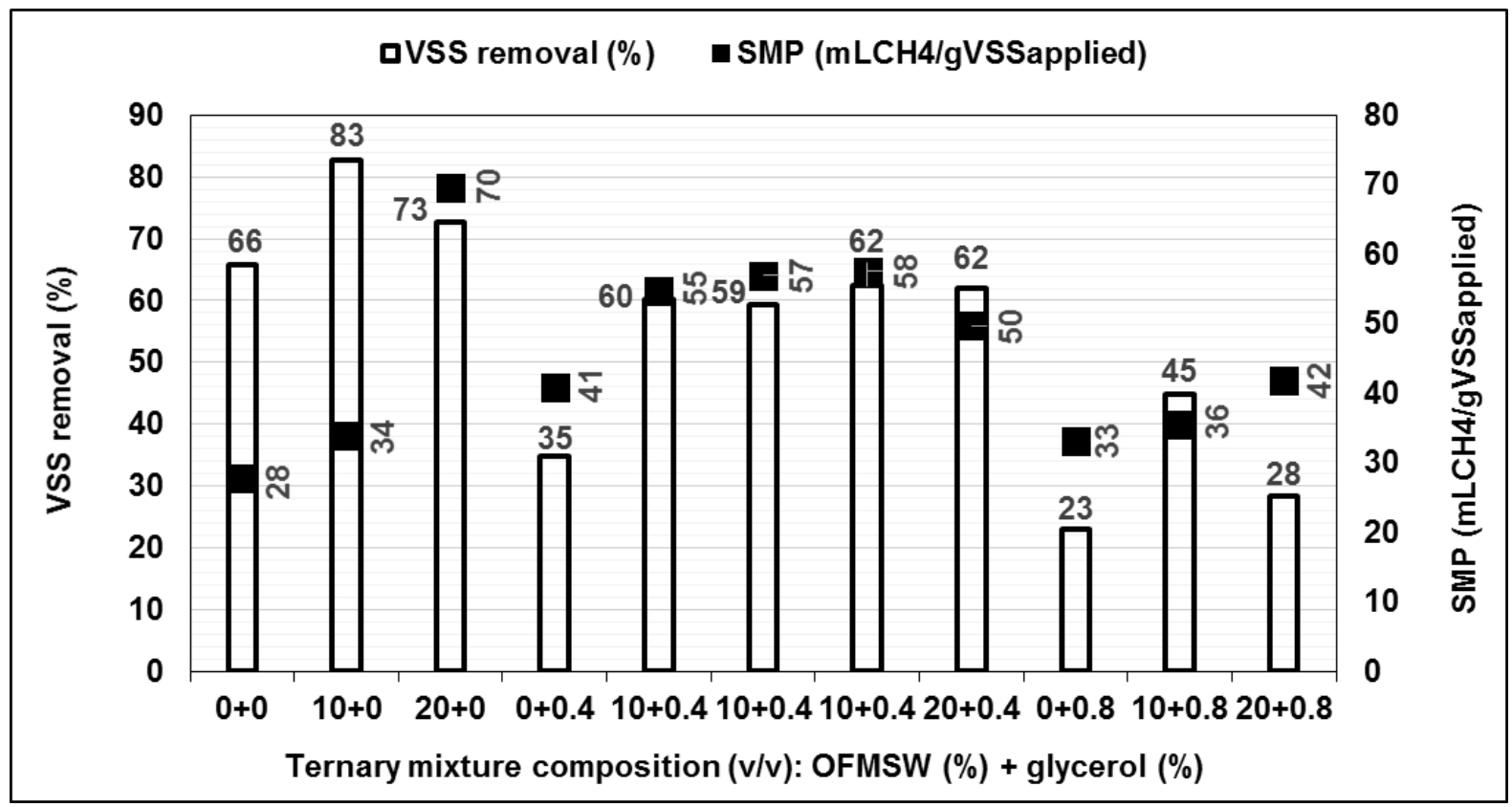

Fig. 6 VSS removal and specific methane production according to different mixture ratios of sludge, FW, and glycerol.

Increasing the proportion of FW in binary sludge mixtures raised VSS removal from $66 \%$ in pure sludge to $83 \%$ and $73 \%$ in mixtures with $10 \%$ and $20 \% \mathrm{FW}$, respectively. In contrast, increasing the proportion of raw glycerol in ternary mixtures with sludge and FW resulted in a lower removal of VSS, despite SMP gain over control in almost all mixtures. For mixtures containing sludge and $10 \% \mathrm{FW}$, VSS removal fell from $83 \%$ to $59 \%$ and $36 \%$ with $0.4 \%$ and $0.8 \%$ glycerol, respectively. While the mixtures of sludge with $20 \%$ FW showed VSS removal of $73 \%$ without glycerol and $62 \%$ and $28 \%$ with $0.4 \%$ and $0.8 \%$ of glycerol. A probable explanation for the lower VSS removal efficiency in the tests with $0.4 \%$ and $0.8 \%$ of glycerol, relative to the control and binary mixtures with sludge and FW, would be a preferential consumption of glycerol in detriment of the insoluble organic constituents (measured as VSS), consistent with the high consumption of glycerol (above $80 \%$ ). Athanasoulia et al. [7], also found SSV removal (25\%) is lower than in the control (36\%), in the co-digestion of sewage sludge with $2 \%$ to $4 \%$ (v/v) glycerol in reactor operating with hydraulic retention time of 12 to 20 d. Fountolakis et al. [19] and Ma et al. [26] establish that the addition of glycerol provides an extra amount of organic matter to the active biomass, which increases its growth and VSS concentration.

According to the planned factorial experiment $3^{2}$, binary mixtures with FW and without glycerol were the ones that presented better values in terms of VSS removal (\%). The increase in glycerol content, with or without the presence of FW, decreased VSS removal. Even the control assay, comprising just sludge digestion, achieved better VSS removal than glycerol binary and ternary mixture assays. With or without the addition of glycerol, the presence of food waste always improved VSS removal. For any content of glycerol, 10\% food waste addition $(\mathrm{v} / \mathrm{v})$ presented higher VSS removal values. However, binary mixtures with FW and without glycerol were not the ones that presented better values in terms of SMP.

Statistica 8 software (StatSoft) generated linear regression curves with coefficient of determination equal to 0.99 for VSSD and to 0.82 for SMP, with $95 \%$ of significance level $(p<0.05)$. Student's t-test was applied in order to evaluate the significance effects on dependent variables (VSSD and SMP) and results are visualized in a Pareto Chart, as shown in Figs. 7 and 8. 


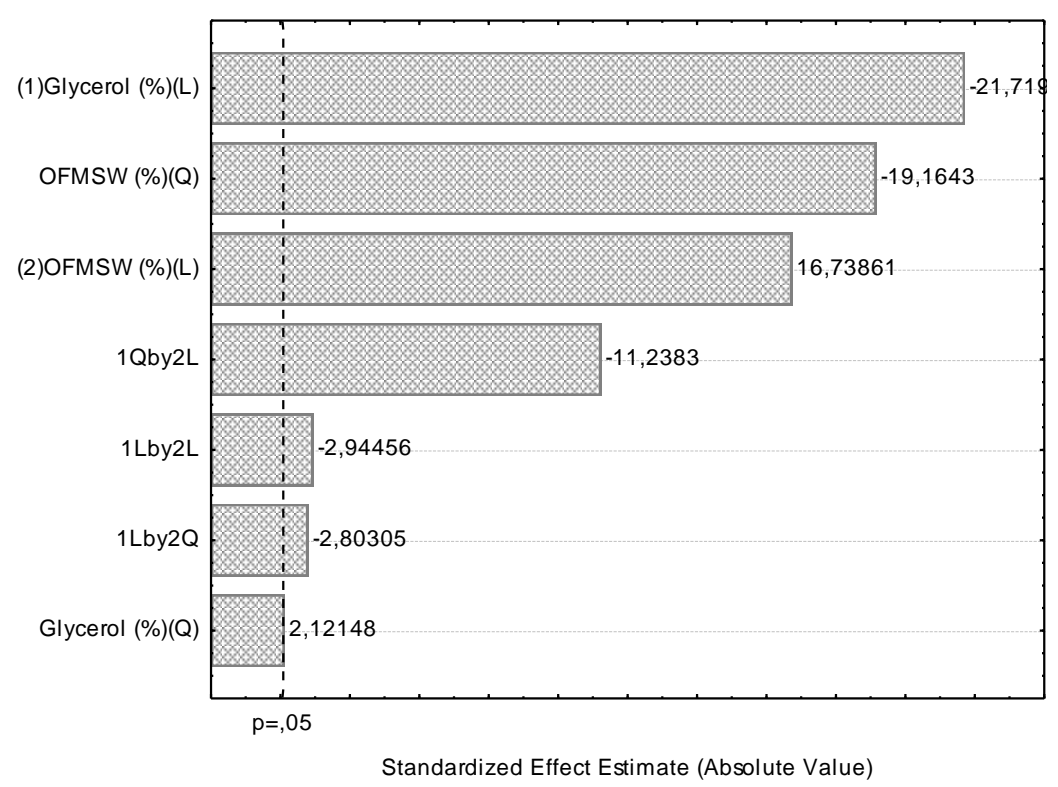

Fig. 7 Pareto Chart representing the effects of glycerol and FW content (expressed as OFMSW) on VSSD $(1=$ raw glycerol and 2 = FW represent factors and interactions).

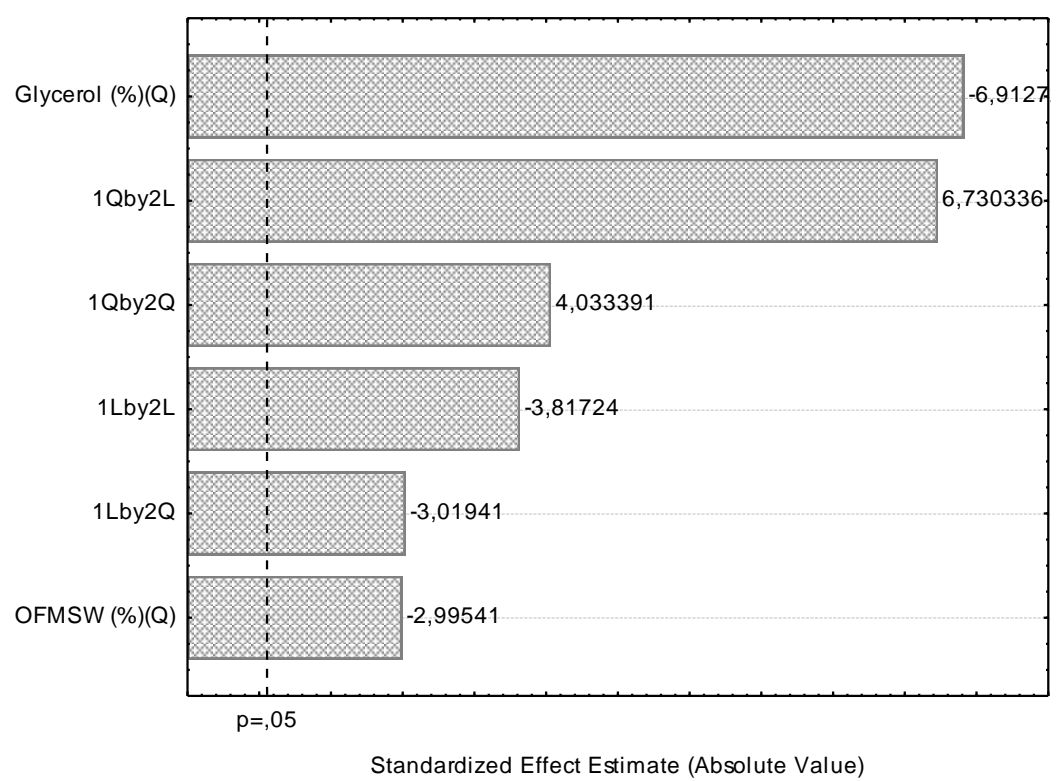

Fig. 8 Pareto's graph representing glycerol and FW content (expressed as OFMSW) effects on SMP $(1=$ raw glycerol and $2=$ FW represent factors and interactions).

The dotted vertical line $(p=0.05$, the tabulated student's $t$ value) indicates the minimum significant effect value for $95 \%$ of confidence level. Values higher than 0.05 indicate that the correspondent factor has importance for the analysis and interpretation, and results indicate that the effect of glycerol content was the most important factor for VSSD and SMP. However, while glycerol has a negative and linear effect on VSSD, it has no linear effect but a negative quadratic effect on SMP. This result can be attributed to the higher availability of carbon in glycerol, contributing to VTS destruction and process stabilization, as already mentioned [19]. At the same time, the increase in readily biodegradable carbon availability contributed to a higher SMP.

The second significant linear effect on VSSD was 
FW, with positive value, indicating increased VSSD relative to increased FW content in the ternary mixture. This conclusion is different from that one obtained during the first phase of experiments, when VS removal decreased according to the increase of FW content. However, the linear effect of FW on SMP was not significant to a $95 \%$ confidence level in student's t-distribution. Both variables FW and glycerol have negative quadratic effect on SMP. Comparison between the magnitude of the most significant effects on the dependent variables shows values 3 to 4 times higher related to VSSD, indicating limitation in the effects of glycerol and FW on SMP.

Figs. 9 and 10 show the surface charts of interactions between glycerol and FW variables. The glycerol and FW interactions also appear as significant on Pareto Charts, which indicated that for a higher SMP, the trials of co-digestion should be conducted with levels of $10 \%$ FW (v/v) and $0.4 \%$ glycerol (v/v) or $20 \% \mathrm{FW}(\mathrm{v} / \mathrm{v})$ without glycerol. On the other hand, high VSSD values were obtained in the range of 10 to $20 \% \mathrm{FW}(\mathrm{v} / \mathrm{v})$ and lower levels of glycerol. However, higher levels of VSSD, up to $60 \%$, were observed in the ternary mixture of $10 \% \mathrm{FW}(\mathrm{v} / \mathrm{v})$ and $0.4 \%(\mathrm{v} / \mathrm{v})$ glycerol. As a general conclusion, based on STATISTICA 8.0 software

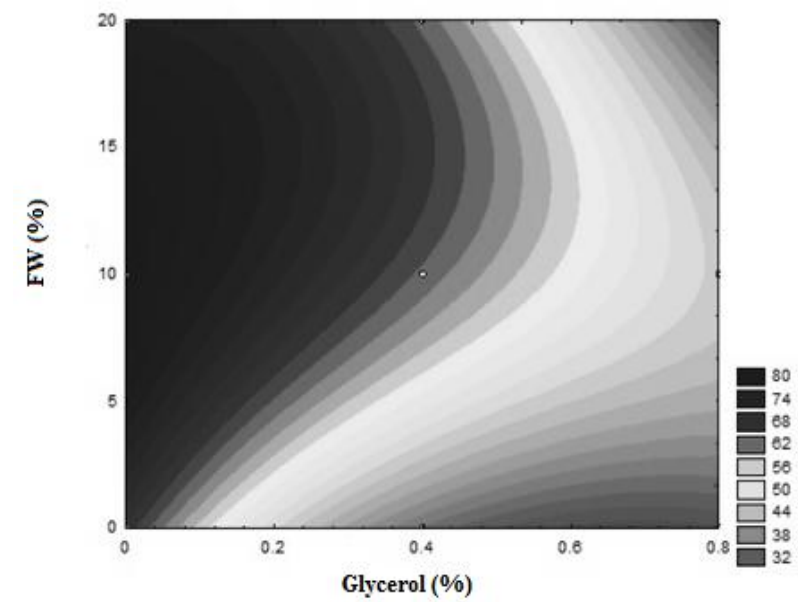

Fig. 9 Response surface describing the interaction of FW (vertical axis-y) and glycerol (horizontal axis-x). Contour lines represent VSSD values $(\%)$ obtained for each combination.

Statistical model: VSSD $(\%)=61.5-17.8 x+1.6 x^{2}+13.7 y-$ $14 y^{2}-1.7 x y-2.8 x y^{2}-11.3 x^{2} y$.

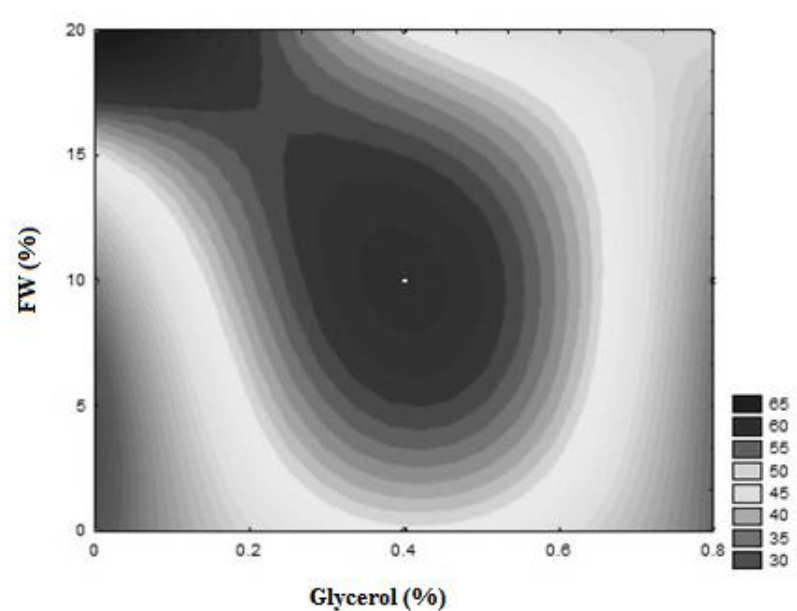

Fig. 10 Response surface describing the interaction of FW (vertical axis-y) and glycerol (horizontal axis-x). Contour lines represent SMP values ( $\mathrm{mL} \mathrm{CH}_{4} / \mathrm{g} \mathrm{VSS}_{\text {applied }}$ ) obtained for each combination.

Statistical model: SMP $\left(\mathrm{mL} \mathrm{CH}_{4} / \mathrm{g} \mathrm{VTS}_{\text {applied }}\right)=58.5-22.9 \mathrm{x}^{2}-$ $9.9 y^{2}-6.9 x y-5.5 x y^{2}+12.2 x^{2} y+18.4 x^{2} y^{2}$.

and statistical analysis according to $95 \%$ of significance level ( $p$-value $<0.05)$, high SMP and VSSD values should be obtained in the ternary mixture of sewage sludge, $10 \% \mathrm{FW}(\mathrm{v} / \mathrm{v})$ and $0.4 \%(\mathrm{v} / \mathrm{v})$ glycerol or in the binary mixture of sludge with $20 \%$ $\mathrm{FW}(\mathrm{v} / \mathrm{v})$.

\section{Conclusions}

(1) FW proved to be a good source of carbon and nutrients for the anaerobic co-digestion process, without any complementary external source. Due to its high percentage of VTS, biogas production and methane content were favored up to the limit of $25 \%$ FW (v/v) added to sewage sludge. Higher values resulted in TVA accumulation and $\mathrm{pH}$ drop.

(2) In general, the addition of lower FW content in the binary mixture with the sewage sludge (10 to $25 \%$ $\mathrm{v} / \mathrm{v}$ ) followed by the initial $\mathrm{pH}$ correction to 7.5, allowed better buffering condition, and a higher VTS removal and SMP was achieved than for the sewage sludge sample control.

(3) Co-digestion of sewage sludge and RG (raw glycerol) according to values lower than $1 \%(\mathrm{v} / \mathrm{v})$ resulted in the increase of methane production and did not impair binary mixture stabilization. The best 
condition was related to the addition of $0.5 \%$ of glycerol (v/v), in which an SMP was 7.8 times greater than that obtained by the sewage sludge sample control.

(4) According to the planned factorial experiment $3^{2}$, a ternary mixture with $10 \% \mathrm{FW}(\mathrm{v} / \mathrm{v})$ and $0.4 \%$ glycerol $(\mathrm{v} / \mathrm{v})$ resulted on high VSSD (average value of $61 \%$ ), equivalent to the value obtained by the sewage sludge sample control (66\%), and with high SMP (average value of $56 \mathrm{~mL} \mathrm{CH}_{4} / \mathrm{g} \mathrm{VSS}_{\text {applied}}$ ), which was twice that achieved by the control.

(5) The planned factorial experiment $3^{2}$ also showed a better condition for the co-digestion of a binary mixture of sewage sludge and $20 \% \mathrm{FW}(\mathrm{v} / \mathrm{v})$, which reached an SMP equal to $70 \mathrm{~mL} \mathrm{CH}_{4} / \mathrm{g} \mathrm{VSS}_{\text {applied, a }}$ value 2.5 times higher than that obtained by the sewage sludge sample control.

\section{Acknowledgements}

This work was supported by project funds from the Brazilian Innovation Agency-FINEP, Reseach National Council (CNPq), and Carlos Chagas Filho Research Foundation-Riode Janeiro State (FAPERJ).

\section{References}

[1] Regueiro, L., Carballa, M., Álvarez, J. A., and Lema, J. M. 2012. "Enhanced Methane Production from Pig Manure Anaerobic Digestion Using Fish and Biodiesel Wastes as Co-substrates.” Bioresource Technology 123 (November): 507-13.

[2] Mata-Alvarez, J., Dosta, J., Romero-Güiza, M. S., Fonoll, X., Peces, M., and Astals, S. 2013. "A Critical Review on Anaerobic Co-digestion Achievements between 2010 and 2013." Renewable Sustainable Energy Reviews 36 (August): 412-27.

[3] Nartker, S., Ammerman, M., Aurandt, J., Stogsdil, M., Hayden, O., and Antle, C. 2014. "Increasing Biogas Production from Sewage Sludge Anaerobic Co-digestion Process by Adding Crude Glycerol from Biodiesel Industry." Waste Management 34 (12): 2567-71.

[4] Gou, C., Yang, Z., Huang, J., Wang, H., Xu, H., and Wang, L. 2014. "Effects of Temperature and Organic Loading Rate on the Performance and Microbial Community of Anaerobic Co-digestion of Waste Activated Sludge and Food Waste.” Chemosphere 105 (June): 146-51.

[5] Zhang, J., Lv, C., Tong, J., Liu, J., Liu, J., Yu, D., Wang,
Y., Chen, M., and Wei, Y. 2016. "Optimization and Microbial Community Analysis of Anaerobic Co-digestion of Food Waste and Sewage Sludge Based on Microwave Pretreatment." Bioresource Technology 200 (January): 253-61.

[6] National Petroleum Agency. 2016. National Production of Pure Biodiesel-B100 (2005-2016) Official Bulletin.

[7] Athanasoulia, E., Melidis, P., and Aivasidis, A. 2014. "Co-digestion of Sewage Sludge and Crude Glycerol from Biodiesel Production.” Renewable Energy 62 (February): 73-8.

[8] Jensen, P. D., Astals, S., Lu, Y., Devadas, M., and Batstone, D. J. 2014. "Anaerobic Co-digestion of Sewage Sludge and Glycerol, Focusing on Process Kinetics, Microbial Dynamics and Sludge Dewaterability." Water Resources 67 (December): 355-66.

[9] Amon, T., Amon, B., Kryvoruchko, V., Bodiroza, V., Pötsch, E., and Zollitsch, W. 2006. "Optimising Methane Yield from Anaerobic Digestion of Manure: Effects of Dairy Systems and of Glycerine Supplementation." International Congress Series 1293 (July): 217-20.

[10] Fountoulakis, M. S., and Manios, T. 2009. "Enhanced Methane and Hydrogen Production from Municipal Solid Waste and Agro-Industrial By-Products Co-digested with Crude Glycerol." Bioresource Technology 100 (12): 3043-7.

[11] Álvarez, J. A., Otero, L., and Lema, J. M. 2010. “A Methodology for Optimising Feed Composition for Anaerobic Co-digestion of Agro-Industrial Wastes." Bioresource Technology 101 (4): 1153-8.

[12] Carmona, M., Lech, A., de Lucas, A., Pérez, A., and Rodriguez, J. F. 2009. "Purification of Glycerol/Water Solutions from Biodiesel Synthesis by Ion Exchange: Sodium and Chloride Removal." Journal of Chemical Technology and Biotechnology 84 (August): 1130-5.

[13] Viana, M. B., Freitas, A. V., Leitão, R. C., Pinto, G. A. S., and Santaella, S. T. 2012. "Anaerobic Digestion of Crude Glycerol: A Review." Environment Technoogy 1 (November): 81-92.

[14] Vijayaraghavan, K., and Ramanujam, T. K. 1999. "Effect of Chloride and Condensable Tannin in Anaerobic Degradation of Tannery Waste Wasters." Bioprocess Engineering 20 (June): 499-503.

[15] Vallero, M. V. G., Hulshoff, Pol., L. W., Lettinga, G., and Lens, P. N. L. 2003. "Effect of $\mathrm{NaCl}$ on Thermophilic (55oc) Methanol Degradation in Sulfate Reducing Granular Sludge Reactors." Water Research 37 (10): 2269-80.

[16] Ito, T., Nakashimada, Y., Senba. K., Matsui, T., and Nishio, N. 2005. "Hydrogen and Ethanol Production from Glycerol-Containing Wastes Discharged after Biodiesel Manufacturing Process." Journal of Bioscience and 
Bioengineering 100 (3): 260-5.

[17] Riffat, R., and Krongthamchat, K. 2006. "Specific Methanogenic Activity of Halophilic and Mixed Cultures in Saline Wastewater." International Journal of Environment and Science Technology 2 (4): 291-9.

[18] Baba, Y., Tada, C., Watanabe, R., Fukuda, Y., Chida, N., and Nakai, Y. 2013. "Anaerobic Digestion of Crude Glycerol from Biodiesel Manufacturing Using a Large-Scale Pilot Plant: Methane Production and Application of Digested Sludge as Fertilizer." Bioresource Technology 140 (July): 342-8.

[19] Fountoulakis, M. S., Petousi, I., and Manios, T. 2010. "Co-digestion of Sewage Sludge with Glycerol to Boost Biogas Production." Waste Management 30 (10): 1849-53.

[20] Siles López, J. A. S., Santos, M. A. M., Pérez, A. F. C., and Martín, A. M. 2009. "Anaerobic Digestion of Glycerol Derived from Biodiesel Manufacturing." Bioresource Technology 100 (23): 5609-15.

[21] Nghiem, L. D., Nguyen, T. T., Manassa, P., Fitzgerald, S. K., Dawson, M., and Vierboom, S. 2014. "Co-digestion of Sewage Sludge and Crude Glycerol for On-demand Biogas Production." Internation Biodeteriorition and Biodegradation 95 (PA): 160-6.

[22] Razaviarani, V., Buchanan, I. D., Malik, S., and Katalambula, H. 2013. "Pilot-Scale Anaerobic Co-digestion of Municipal Wastewater Sludge with Restaurant Grease Trap Waste.” Journal of Environment Managemennt 123 (July): 26-33.

[23] Razaviarani, V., and Buchanan, I. D. 2015. "Anaerobic Co-digestion of Biodiesel Waste Glycerin with Municipal Wastewater Sludge: Microbial Community Structure Dynamics and Reactor Performance." Bioresource Technology 182 (April): 8-17.

[24] Rivero, M., Solera, R., and Perez, M. 2014. "Anaerobic Mesophilic Co-Digestion of Sewage Sludge with Glycerol: Enhanced Biohydrogen Production." International Joournal of Hydrogen Energy 39 (6): 2481-8.

[25] Silvestre, G., Fernandez, B., and Bonmatt, A. 2015. "Addition of Crude Glycerine as Strategy to Balance the $\mathrm{C} / \mathrm{N}$ Ratio on Sewage Sludge Thermophilic and Mesophilic Anaerobic Co-digestion." Bioresource Technology 193 (October): 377-85.

[26] Ma, J., van Wambeke, M., Carballa, M., and Verstraete, W. 2008. "Improvement of the Anaerobic Treatment of Potato Processing Wastewater in a UASB Reactor by Co-digestion with Glycerol." Biotechnology Letters 30 (5): 861-7.

[27] Astals, S., Ariso, M., Galí, A., and Mata-Alvarez, J. 2011. "Co-digestion of Pig Manure and Glycerine: Experimental and Modelling Study." Journal of Environment Management 92 (4): 1091-6.
[28] Robra, S., Cruz, R. S., Oliveira, A. M., Almeida Neto, J. A., and Santos, J. V. 2010. "Generation of Biogas Using Crude Glycerin from Biodiesel Production as a Supplement to Cattle Slurry." Biomass Bioenergy 34 (9): 1330-5.

[29] Heaven, S., Salter, A. M., and Banks, C. J. 2011. "Integration of On-farm Biodiesel Production with Anaerobic Digestion to Maximise Energy Yield and Greenhouse Gas Savings from Process and Farm Residues." Bioresource and Technology 102 (17): 7784-93.

[30] Astals, S., Nolla-Ardèvol, V., and Mata-Alvarez, J. 2012. "Anaerobic Co-digestion of Pig Manure and Crude Glycerol at Mesophilic Conditions: Biogas and Digestate." Bioresource Technology 110 (April): 63-70.

[31] Martín, M. A., Fernández, R., Serrano, A., and Siles, J. A. 2013. "Semi-Continuous Anaerobic Co-digestion of Orange Peel Waste and Residual Glycerol Derived from Biodiesel Manufacturing." Waste Management 33 (7): 1633-9.

[32] Serrano, A., Siles, J. A., Chica, A. F., and Martin, M. A. 2014. "Improvement of Mesophilic Anaerobic Co-digestion of Agri-Food Waste by Addition of Glycerol." Journal of Environment Management 140 (July): 76-82.

[33] Marañón, E., Castrillón, L., Quiroga, G., Fernández-Nava, Y., Gómez, L., and García, M. M. 2012. "Co-digestion of Cattle Manure with Food Waste and Sludge to Increase Biogas Production.” Waste Management 32 (10): 1821-5.

[34] Dubois, M., Gilles, K. A., Hamilton, J. K., Rebers, P. A., and Smith, F. 1956. "Colorimetric Method for Determination of Sugars and Related Compounds." Analitycal Chemistry 28 (3): 350-6.

[35] Lowry, O. H., Rosebrough, N. J., Farr, A. L., and Randall, R. J. 1951. "Protein Measurement with the Folin Phenol Reagent." Journal of Biology and Chemistry 193 (November): 265-76.

[36] Dilallo, R., and Albertson, O. R. 1961. "Volatile Acids by Direct Titration." Journal of Water Pollution Control Fed 23 (4): 356-5.

[37] Ripley, L. E., Boyle, W. C., and Converse, J. C. 1986. "Improved Alkalimetric Monitoring for Anaerobic Digestor of High-Strength Wastes." Journal of Water Pollution Control Fed 58 (5): 406-11.

[38] Bondioli, P., and Bella, L. D. 2005. "An Alternative Spectrophotometric Method for the Determination of Free Glycerol in Biodiesel." Europen Jorunal of Lipid Science and Technology 107 (3): 153-7.

[39] American Public Health Association. 2005. "Standard Methods for the Examination of Water and Wastewater." American Public Health Association/American Water Works Association/Water Environment Federation, Washington DC. 

Sewage Sludge, Food Waste, and Glycerol

[40] Li, Y., Park, S. Y., and Zhu, J. 2011. "Solid-State Anaerobic Digestion for Methane Production from Organic Waste." Renewable Sustainable Energy Reviews 15 (1): 821-6.

[41] Kim, J., and Kang, C. M. 2015. "Increased Anaerobic Production of Methane by Co-digestion of Sludge with
Microalgal Biomass and Food Waste Leachate." Bioresource and Technology 189 (August): 409-12.

[42] Kim, H.-W., Han, S.-K., and Shin, H.-S. 2003. "The Optimisation of Food Waste Addition as a Co-substrate in Anaerobic Digestion of Sewage Sludge." Waste Management Research 21 (6): 515-26. 